\title{
ENVIRONMENTAL FACTORS RELATED TO GALL RUST DISEASE DEVELOPMENT ON FALCATARIA MOLUCCANA (MIQ.) BARNEBY \& J. W. GRIMES AT BRUMAS ESTATE, TAWAU, SABAH, MALAYSIA
}

\author{
RAHAYU, S. $.^{1,3}-$ SEE, L. S. ${ }^{2}-$ SHUKOR, N. A. A. ${ }^{3}-$ SALEH, G. ${ }^{4}$

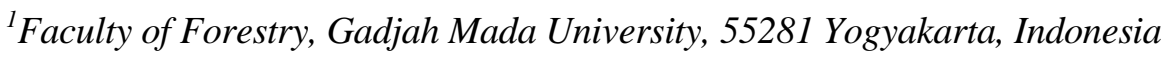 \\ ${ }^{2}$ Forest Research Institute Malaysia, 52109 Kepong, Selangor, Malaysia \\ ${ }^{3}$ Faculty of Forestry, University Putra Malaysia, 43400 Seri Kembangan, Selangor, Malaysia \\ ${ }^{4}$ Faculty of Agriculture, University Putra Malaysia, 43400 Seri Kembangan, Selangor, Malaysia \\ *Corresponding author \\ e-mail: tatarahayu@yahoo.com; phone: +62-274-512-102; fax: +62-274-550-541
}

(Received $13^{\text {th }}$ May 2018; accepted $1^{\text {st }}$ Nov 2018)

\begin{abstract}
Gall rust disease caused by Uromycladium falcatarium (Sacc.) is one of the most destructive diseases of Falcataria moluccana plantations in parts of South-East Asia. The disease causes severe damage throughout all developmental stages from seedlings to mature trees. Chocolate brown, cauliflower- or whip-like galls are observed on stem, branch, petiole, shoot and pod. The objectives of this study at Brumas Estate, Tawau, Sabah were to (i) determine the status of gall rust disease, (ii) examine the relationship between disease incidence and environmental factors that may influence disease development, and (iii) predict the origin gall-rust spores. The sampling intensity was $10 \%$ of the total area at each site. Three blocks at each site contained three replicates, each containing three plots of 10 trees for observations. More open sites, flat topography, absence of fog, greater age and lower altitude were associated with reduced gall rust disease incidence and severity; high relative humidity and low wind speeds promoted gall rust disease development. As winds blew predominantly from the north-east, gall rust spores may have spread from the north, probably from the Philippines to Tawau.
\end{abstract}

Keywords: environmental factors, gall rust disease, Falcataria moluccana, rust fungus, fog

\section{Introduction}

Falcataria moluccana (Miq.) Barneby and J. W. Grimes (batai) is a valuable multipurpose tree species used in forest plantations in South-East Asia, particularly Malaysia and Indonesia. Gall rust caused by Uromycladium tepperianum (Sacc.) (Rosso and Hansen, 2003) then updated to be U. Falcatarium (Doungsaard et al., 2015) is the most destructive disease of $F$. moluccana plantations in parts of this region. The disease was first reported in 1990 as an epidemic outbreak in Mindanao Island; by 1995 the disease had spread throughout the Philippines, including Luzon and Visayas islands (Braza, 1997; Eusobio et al., 1990). In 1993, the disease caused severe infection on $F$. moluccana plantations in Sipitang, on the west coast of Sabah, Malaysia (Lee, 2004), and Brumas Estate near Tawau, also in Sabah. In Indonesia, gall rust disease was first found in F. moluccana plantations on Seram Island in the Moluccas at 1996 (Anggraeni, 2006), then in Sorowako in South Celebes (Kasno and Hadi, 2005), and then throughout much of the plantation estate in Java (Rahayu et al., 2010). Between 1999 and 2002 gall rust disease was observed throughout all the coffee-growing districts of East Timor where F. moluccana was planted as a shade tree (Old and Cristovao, 2003; Fig. 1). The 
disease causes severe damage to all developmental stages of $F$. moluccana from seedlings to mature trees in the field. Chocolate brown, cauliflower-like or whip-like galls on stem, branch, petiole, shoot and pod are observed. Affected plant parts and severely infected trees die prematurely (Braza, 1997; Morris, 1987; Old and Cristovao, 2003; Rahay et al., 2010; Rosso and Hansen, 2003). Due to its host specificity, an Australian source of $U$. falcatarium was selected as a suitable biological control agent for an invasive tree, Acacia saligna in the Western Cape Province of South Africa (Morris, 1987).

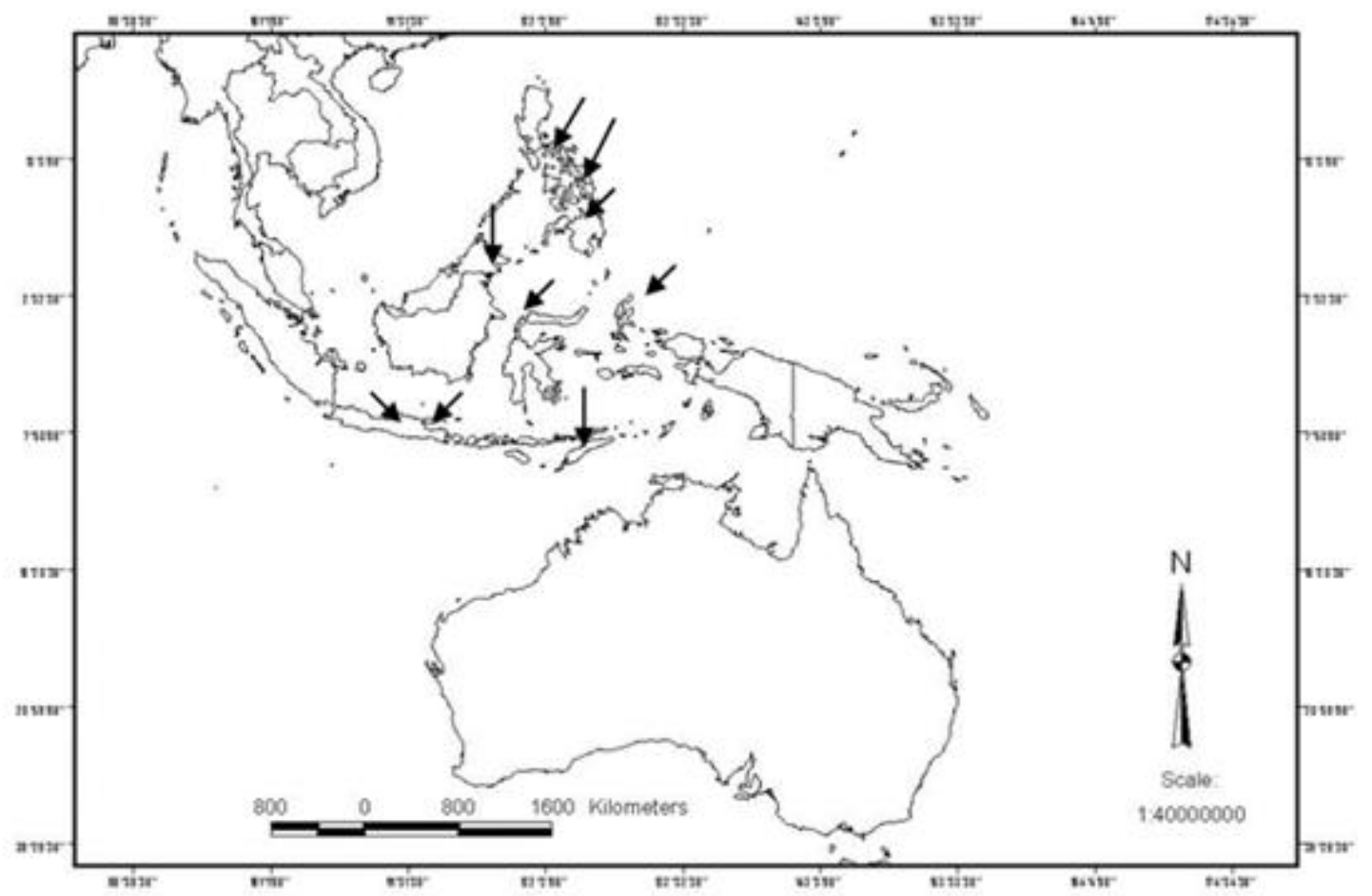

Figure 1. Known distribution of gall rust disease caused by Uromycladium spp. on Falcataria moluccana in South East Asia, illustrated by black arrow

As epidemic diseases such as gall rust are polycyclic, the causes of disease outbreak can only be determined if the environmental and forest conditions under which it occurs are well understood; these conditions include climate, altitude, topography and stand characteristics (Sache, 2000). Temperature and humidity, and their interaction are often the most important factors affecting the length of a disease cycle (Bowen, 2003). Information on the effect of local weather conditions on the occurrence of gall rust disease caused by Uromycladium spp. in batai plantations is sparse, though that for other rust diseases may help explain disease development. For example, with respect to altitude, the needle cast disease Phaeocryptopus gaeumannii of Douglas fir in coastal forests of Washington and Oregon appeared to be more severe at low altitudes, on southern slopes or on sites with high rainfall and closer to the coast (Hamilton, 1959; Hansen et al., 2000). At SFI in Sabah, the most severe gall rust disease occurred at altitudes > $900 \mathrm{~m}$ a.s.l (Anonymous, 1993); and in East Timor at altitudes between 700 and $900 \mathrm{~m}$ a.s.l. in the mountains south-west of Dili (Morris, 1987). However, there were no explanations as to why the disease was more severe at these altitudes. High 
elevation areas, where the environmental conditions appear conducive to rust development, are not considered for planting of $F$. moluccana in the Philippines (Braza, 1997). A possible explanation is the foggy conditions and intermittent showers which occur at high elevations and which induce high levels of spore production, and which favour rust infection (Hoff, 1986).

Wind currents are one of the most important means by which plant disease inoculum is dispersed or spread over a geographical area. Urediniospores of P. graminis $\mathrm{f}$. sp. tritici, which are relatively small, have been found to be carried by wind up to $680 \mathrm{~km}$ (420 miles) from their source (Moore, 1970). Spores of $U$. falcatarium have been confirmed to be spread by wind and are disseminated when separated from the fruit bodies (Franje et al., 1993; Hamilton, 1959; Braza, 1997; Magyar and Manninger, 2004; Serdani, 2001). As many authors mention, wind is probably the most important factor in spore release of the Uredinales (Carter et al., 1970; Hirst, 1961; Sache, 2000; Smith, 1966). Wind gusts and wind direction are important as well (Sache, 2000). Spore-free winds should reduce spore concentration by dilution or blow-off (Hamilton, 1959). Greater wind speeds and higher temperatures caused better dissemination of spores of Melampsoridium betulinum (Fries) Kleb (Vourinen and Helander, 1995). Solar radiation can both inhibit and stimulate germination of fungal spores. The concentration of hyaline uredospores of Cronartium spp., Melampsora spp. and Melampsoridium spp. was increased by solar radiation, low temperature, low dew point, evaporation and long drought periods. The viability of spores of $U$. falcatarium on $F$. moluccana in vitro was decreased by exposure to $5 \mathrm{~h}$ of direct sunlight (Franje et al., 1993). Since the global climate change starts to take place in the recent years, the incidence of gall rust disease were increased. Some new location which previously not infected by gall rust fungus were infected nowadays. The objectives of this study were to (i) determine the status of gall rust disease at Brumas Estate, (ii) examine the relationship between incidence of gall rust disease and local site factors, including meteorological factors, and (iii) predict the origin gall rust spore sources.

\section{Materials and methods}

\section{Site study}

The forest plantation at Brumas Estate is dominated by Acacia mangium, $F$. moluccana, Gmelina arborea, Eucalyptus deglupta, Shorea spp., and Tectona grandis. As the plantings of each species are scattered in the estate, gall rust disease monitoring was conducted at six separate sites (Fig. 2). Site selection was based on the age of the $F$. moluccana stand (Table 1). Each site were represented their age of the trees. The distance among each site were vary from 0.5 to $5 \mathrm{~km}$. The most distant site from other sites were site $1 \mathrm{~F}$ which located at Sungai Udin.

\section{Plot establishment}

The sampling intensity was $10 \%$ of the total area at each site. Three permanent sampling blocks, first located $10 \mathrm{~m}$ from the road, followed by the other two blocks that placed deeper into the forest. The distance between blocks was at least $100 \mathrm{~m}$ from the nearest blocks. Each block was divided into three replicates with 10-tree plots per replicate. 


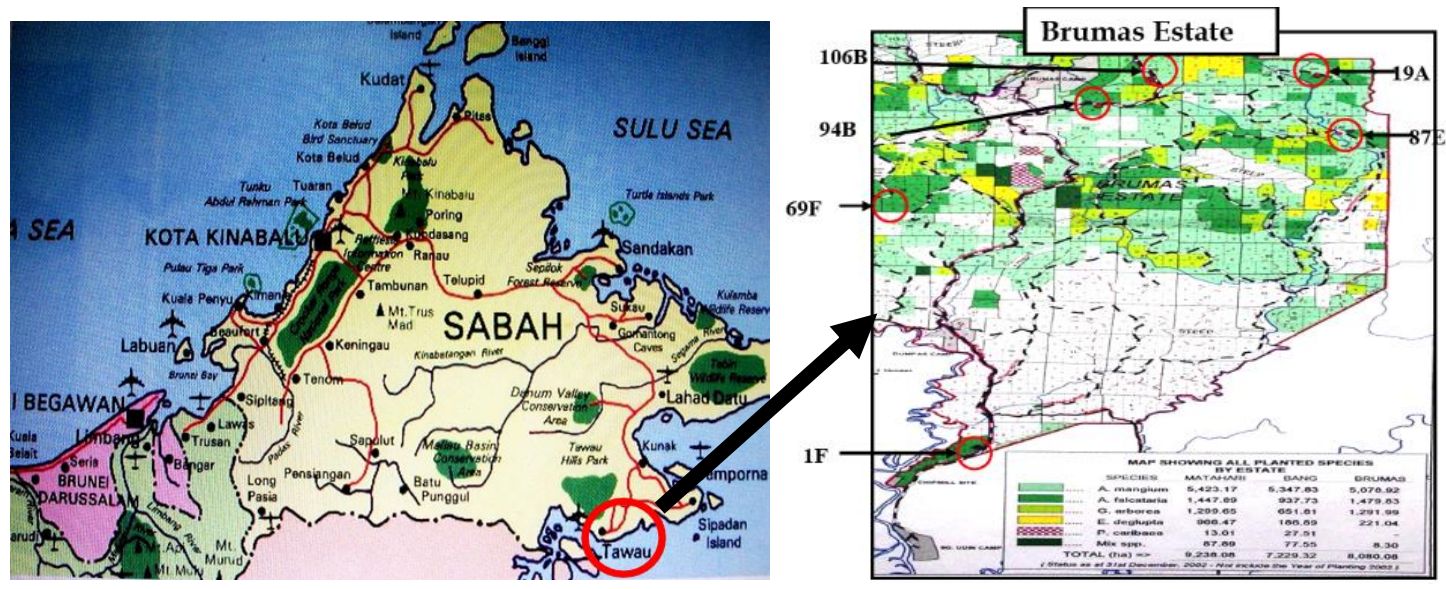

Figure 2. Study site of gall rust disease monitoring (illustrated by red circle) on F. moluccana plantation at Brumas Estate, Tawau, Sabah, Malaysia

Table 1. Description of sites monitored at Brumas Estate, Tawau, Sabah, Malaysia, between October 2003 and March 2005

\begin{tabular}{|c|c|c|c|c|c|c|c|}
\hline Site & $\begin{array}{c}\text { Age } \\
\text { (year) }\end{array}$ & $\begin{array}{l}\text { Altitude } \\
\text { (m.a.s.l) }\end{array}$ & $\begin{array}{l}\text { Longitude } \\
\text { (E) }\end{array}$ & $\begin{array}{l}\text { Latitude } \\
(\mathbf{N})\end{array}$ & Topography & $\begin{array}{c}\text { Total area } \\
\text { (ha) }\end{array}$ & $\begin{array}{c}\text { Foggy } \\
\text { condition }\end{array}$ \\
\hline $87 \mathrm{E}$ & 2 & $159-166$ & $117^{\circ} 44^{\prime} 151^{\prime \prime}$ & $04^{\circ} 37^{\prime} 13^{\prime \prime}$ & Flat & 25.9 & Mist \\
\hline 106B & 3 & $286-300$ & $117^{\circ} 46^{\prime} 071^{\prime \prime}$ & $04^{\circ} 38^{\prime} 7^{\prime \prime}$ & Undulating & 24.3 & Fog \\
\hline $69 \mathrm{~F}$ & 4 & $115-160$ & $117^{\circ} 47^{\prime} 11^{\prime \prime}$ & $04^{\circ} 38^{\prime} 9^{\prime \prime}$ & Flat & 18.8 & Haze \\
\hline $109 \mathrm{~A}$ & 5 & $260-280$ & $117^{\circ} 48^{\prime} 151^{\prime \prime}$ & $04^{\circ} 38^{\prime} 13^{\prime \prime}$ & Flat & 27.9 & Mist \\
\hline $94 \mathrm{~B}$ & 6 & $278-280$ & $117^{\circ} 45^{\prime} 11^{\prime \prime}$ & $04^{\circ} 37^{\prime} 21^{\prime \prime}$ & Undulating & 28.3 & Fog \\
\hline $1 \mathrm{~F}$ & 8 & 40 & $117^{\circ} 43^{\prime} 11^{\prime \prime}$ & $04^{\circ} 37^{\prime} 6^{\prime \prime}$ & Flat & 21.9 & No fog \\
\hline
\end{tabular}

\section{Data collection}

The primary data collected were gall rust disease score, and local site conditions: topography, fog level, tree age, altitude, and degree of forest opening. Data were collected every six months, viz. October 2003, April 2004 and October 2004. Meteorological data for the period January 1993 to January 2005 were obtained from the Brumas meteorological station which is located inside in Brumas plantation office, with the most distant of the sampling site was $5 \mathrm{~km}$ and all the meteorological data were based on actual data taken automatically everyday.

\section{Gall rust disease score}

Gall rust disease produces easily recognizable galls on the trunk, branch and shoots of trees, which are globose, several centimetres in diameter and reddish, brown or black in colour (Fig. 3). Since most trees at all locations were at least $6 \mathrm{~m}$ tall, galls were observed in the crown and on the trunk only. According to the range of gall rust disease symptom at Brumas plantation, index scores were self-developed and therefore grouped quantitatively into five classes (Table 2). 


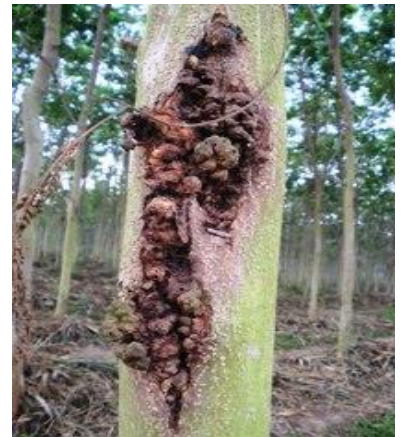

a

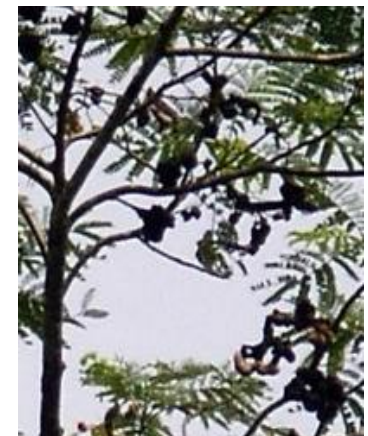

b

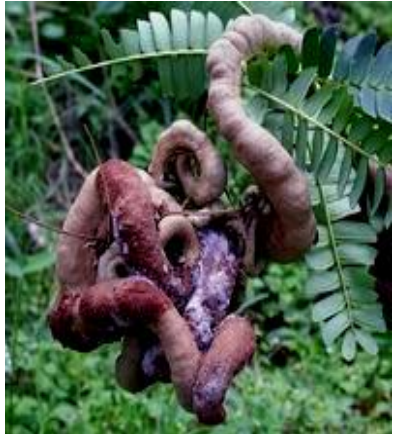

Figure 3. a. Gall in the trunk. b. Gall in the branch.c. The shape of gall in the crown or branch

Table 2. Index score of gall rust presence on F. moluccana trees at Brumas Estate

\begin{tabular}{c|c}
\hline Index score & Presence of galls on tree crown and trunk \\
\hline 0 & No galls \\
1 & Gall formation $<50 \%$ of tree crown, no galls on the trunk \\
3 & Gall formation $<50 \%$ of tree crown, galls $<50 \%$ of the trunk \\
4 & Galls formation $>50 \%$ of tree crown, galls $<50 \%$ of the trunk \\
\hline
\end{tabular}

\section{Local site conditions}

Altitude was measured using a portable GPS (model Garmin 12 XL). Based on the site gradient, topography was classified into slope or undulating determined as 1 for flat with gradient $<10^{\circ}$, undulating as 2 for gradient in between $10^{\circ}-30^{\circ}$ and, 3 for gradient $>30^{\circ}$. Based on the height and density of the surrounding vegetation, forest opening was classified as open (2), intermediate (1) and closed (0) (Table 3).

Table 3. The classification of forest opening on Brumas Estate

\begin{tabular}{c|c}
$\begin{array}{c}\text { Forest } \\
\text { opening }\end{array}$ & Site description \\
\hline 0 & $\begin{array}{r}\text { Open: height and stand density of the vegetation surrounding the } F \text {. moluccana plantation } \\
\text { is relatively low; includes grass and logged over areas following clear cutting } \\
\text { Intermediate: height and stand density of the vegetation surrounding the site similar to } \\
\text { that of the } F \text {. moluccana plantation } \\
\text { Closed: height and density of the vegetation surrounding the } F . \text { moluccana plantation } \\
\text { relatively high; includes secondary forest and old stands }\end{array}$ \\
\hline
\end{tabular}

The foggy condition were measured based on visibility at the site, and have been incorporated from another meteorological factors e.g.: relative humidity and temperature also dew points, thus the foggy condition were not included into meteorological factors. Based on Gultepe (Gultepe, 2007), foggy condition were categorized into: $0=$ no fog, haze or mist; $1=$ haze (visibility between $2 \mathrm{~km}$ to $5 \mathrm{~km}$ ); 2 = mist (visibility between $1 \mathrm{~km}$ to $2 \mathrm{~km}$ ); 3 = fog (visibility less than $1 \mathrm{~km}$ ). 


\section{Data assessment}

Based on the index score of the presence of gall rust, gall rust disease incidence (DI) and severity (DS) for each plot were calculated using the method modified from (Chester, 1959) using following formulae:

$$
\begin{gathered}
\text { Disease incidence }(\mathrm{DI})=\frac{n}{N} \times 100 \% \\
\text { Disease severity }(\mathrm{DS})=\frac{\left(\mathrm{n}_{0} \times \mathrm{z}_{0}\right)+\left(\mathrm{n}_{1} \times \mathrm{z}_{1}\right)+\ldots+\left(\mathrm{n}_{5} \times \mathrm{z}_{5}\right)}{N x Z} \times 100 \%
\end{gathered}
$$

where:

DI $=$ Disease incidence, $\mathrm{DS}=$ Disease Severity, $\mathrm{n}=$ Number of infected trees $\mathrm{n}_{0}, \mathrm{n}_{1}, \mathrm{n}_{2}, \mathrm{n}_{3}, \mathrm{n}_{4}=$ number of trees with index score $0,1,2,3$ and 4 $\mathrm{Z}_{0}, \mathrm{Z}_{1}, \mathrm{Z}_{2}, \mathrm{Z}_{3}, \mathrm{Z}_{4}, \mathrm{Z}_{5}=$ index score of gall rust presence $0,1,2,3$, and 4 $\mathrm{N}=$ Total number of trees in one plot (10); $\mathrm{Z}=$ the highest score (4)

Gall rust disease status at each site was rated based on value of gall rust disease incidence (DI) and severity (DS) and they were later classified for the status as summarized in Table 4.

Table 4. Gall rust disease incidence and severity status on F. moluccana in Brumas Estate, Tawau, Sabah, Malaysia

\begin{tabular}{c|c|c|c}
\hline Value of disease incidence (\%) & Incidence status & Value of disease severity (\%) & Severity status \\
\hline$<10$ & Rare & 0 & Nil \\
$10-<25$ & Occasional & $<25$ & Low \\
$25-<50$ & Common & $25-<50$ & Medium \\
$50-<75$ & Very common & $50-<75$ & Severe \\
$>75$ & Widespread & $75-100$ & Very severe \\
\hline
\end{tabular}

\section{Relationship between gall rust disease incidence and severity with local condition and meteorological factors in the estate}

The incidence of gall rust disease is influenced by the interaction of many factors ranging from host, environment and pathogen. In order to indicate the dominant local site and meteorological factors influencing gall rust disease incidence and severity, the five local factors (tree age, altitude, topography, fog condition, and forest opening) and the six meteorological factors (sunshine hours, wind speed, relative humidity, rainfall, no. of rain days, and temperature) were paired with the mean of incidence and severity of gall rust disease at each time of monitoring. A regression equation was then constructed, and used to determine the dominant factor influencing gall rust disease.

\section{Statistical analysis}

Analysis of variance was used to test the effect of difference of locations, and block means for disease incidence and disease severity. Step-wise multiple linear regression analysis was used in variable selection for the gall rust disease regression model. The 
relationship between gall rust disease incidence and severity with local site conditions and meteorological factors was estimated using the following linear regression model:

$$
Y_{t}=\beta_{0}+\beta_{1} X_{1}+\beta_{2} X_{2}+\beta_{3} X_{3}+\beta_{4} X_{4}+\beta_{5} X_{5}
$$

where:

$\mathrm{Y}_{\mathrm{t}}=$ estimate of gall rust disease incidence or severity at time $\mathrm{t}$

$\beta_{0}=$ estimate of gall rust disease presence for $Y_{t}$

$X_{1}=$ age of the tree, $X_{2}=$ altitude, $X_{3}=$ topography, $X_{4}=$ fog condition, $X 5=$ forest opening

$\beta_{1}=$ adjusted on $Y_{t}$, due to 1 unit change in $X_{1}$, where $X_{2}$ to $X_{8}$ are constant

$\mathrm{B}_{2}=$ adjusted on $\mathrm{Y}_{\mathrm{t}}$, due to 1 unit change in $\mathrm{X}_{2}$, where $\mathrm{X}_{1}$ and $\mathrm{X}_{3}$ to $\mathrm{X}_{8}$ are constant

$\mathrm{B}_{3}=$ adjusted on $\mathrm{Y}_{\mathrm{t}}$, due to 1 unit change in $\mathrm{X}_{3}$, where $\mathrm{X}_{1}, \mathrm{X}_{2}$ and $\mathrm{X}_{4}$ to $\mathrm{X}_{8}$ are constant

$\mathrm{B}_{4}=$ adjusted on $\mathrm{Y}_{t}$, due to 1 unit change in $\mathrm{X}_{4}$, where $\mathrm{X}_{1}$ to $\mathrm{X}_{3}$ and $\mathrm{X}_{5}$ to $\mathrm{X}_{8}$ are constant

$\mathrm{B}_{5}=$ adjusted on $\mathrm{Y}_{\mathrm{t}}$, due to 1 unit change in $\mathrm{X}_{5}$, where $\mathrm{X}_{1}$ to $\mathrm{X}_{4}$ and $\mathrm{X}_{6}$ to $\mathrm{X}_{8}$ are constant

$$
\mathrm{Y}=\beta_{0}+\beta_{\mathrm{ss}} X_{\mathrm{ss}}+\beta_{\mathrm{ws}} X_{\mathrm{ws}}+\beta_{\mathrm{rh}} \mathrm{X}_{\mathrm{rh}}+\beta_{\mathrm{rf}} \mathrm{X}_{\mathrm{rf}}+\beta_{\mathrm{rd}} \mathrm{X}_{\mathrm{rd}}+\beta_{\mathrm{t}} \mathrm{X}_{\mathrm{t}}
$$

where:

$\mathrm{Y}=$ estimate of gall rust disease incidence and severity

$\beta_{0}=$ estimate of gall rust disease incidence and severity for $Y$

$X_{\mathrm{ss}}=$ no. of sunshine hours, $X_{\mathrm{ws}}=$ wind speed, $X_{\mathrm{rh}}=$ relative humidity, $X_{\mathrm{rf}}=$ rainfall,

$\mathrm{X}_{\mathrm{rd}}=$ no. of rain days and $\mathrm{X}_{\mathrm{t}}=$ mean temperature

$\beta_{\mathrm{ss}}=$ adjusted on $Y$, due to 1 unit change in $X_{\mathrm{ss}}$, where other factors are constant

$\mathrm{B}_{\mathrm{ws}}=$ adjusted on $\mathrm{Y}$, due to 1 unit change in $\mathrm{X}_{\mathrm{ws}}$ where other factors are constant

$\mathrm{B}_{\mathrm{rh}}=$ adjusted on $\mathrm{Y}$, due to 1 unit change in $\mathrm{X}_{\mathrm{rh}}$, where other factors are constant

$B_{\mathrm{rf}}=$ adjusted in $Y$, due to 1 unit change in $X_{\mathrm{rf}}$, where other factors are constant

$\mathrm{B}_{\mathrm{rd}}=$ adjusted on $\mathrm{Y}$, due to 1 unit change in $\mathrm{X}_{\mathrm{rd}}$, where other factors are constant

$\mathrm{B}_{\mathrm{t}}=$ adjusted on $\mathrm{Y}$, due to 1 unit change in $\mathrm{X}_{\mathrm{t}}$, where other factors are constant

All analyses were conducted using the statistical package of the Statistical Analysis Systems Institute Inc., version 9.13 (2004).

\section{Results}

\section{Gall rust disease status}

Gall rust disease incidence in October 2003 ranged from rare to widespread (Fig. 4a). However, by April 2004, disease incidence at all sites was widespread. By October 2005, disease incidence at some sites had decreased and the status ranged from common to widespread.

Differences in gall rust disease incidence between sites throughout the experiment were not significantly different, except at site 87E in October 2003, when it was significantly lower than at the other sites (Fig. 4a). A similar trend was observed for gall rust disease severity which in October 2003 ranged from low to severe and in April 2004 from moderate to very severe. Gall rust severity in October 2004 was similar to that in October 2003. There were no significant differences in disease severity except for site 94B in April 2004 when it was less than at the other sites. In addition, there was no gall rust disease incidence at all at site $1 \mathrm{~F}$ (Fig. $4 b$ ). 


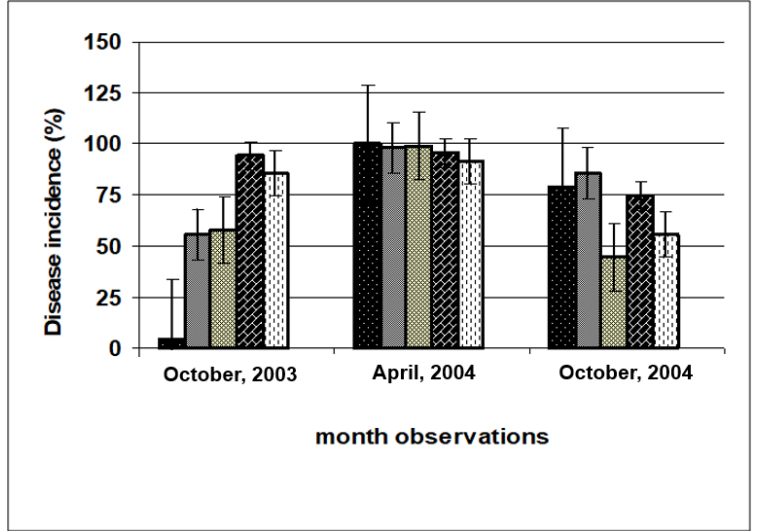

$\mathbf{a}$

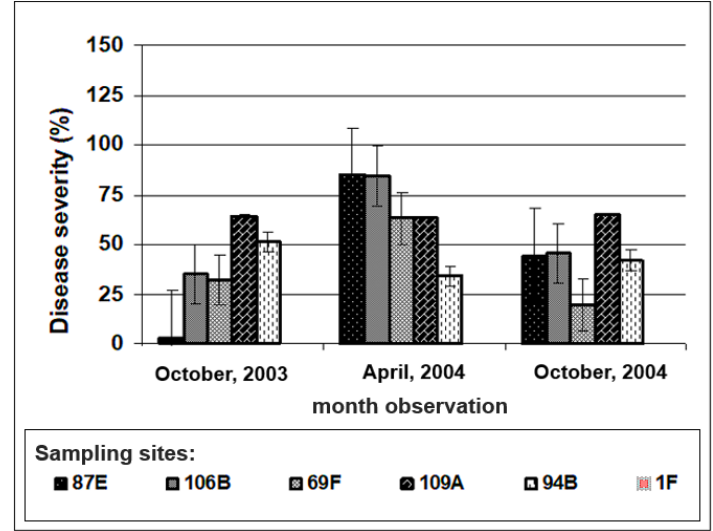

b

Figure 4. Gall rust disease incidence (a) and severity (b) at F. moluccana plantations in Brumas Estate, Tawau, Sabah, Malaysia in October 2003, and April and October 2004; vertical bars represent standard error

\section{Relationships between gall rust disease incidence and local site conditions}

Multiple regression analysis confirmed the selection of local site factors that were significantly related to the estimated factor; factors which were not significant were removed from the equation (Table 5). Gall rust disease incidence in October 2003 increased with increasing slope, and more closed trees canopy of surrounding $F$. moluccana trees (Eq. 1). However, degree of forest opening was most related to gall rust disease incidence. In April 2004, gall rust incidence decreased with tree age and slope (topography), but increased with degree of foggy condition (Eq. 2), fog condition was the most important factor. In October, 2004, disease incidence decreased with tree age, and increased with altitude (Eq. 3); tree age was the more important factor.

Table 5. Linear regression equation used for estimating gall rust disease incidence in Brumas Estate, Tawau, Sabah, Malaysia

\begin{tabular}{c|c|c}
\hline Month monitored & Linear regression equation & $\mathbf{R}^{\mathbf{2}(\%)}$ \\
\hline October, 2003 & $\mathrm{Y}_{\mathrm{DI}}=-2.9+13.4 \mathrm{X}_{3}+41.6 \mathrm{X}_{5} \ldots \ldots \ldots \ldots \ldots$ (Eq.1) & 80 \\
April, 2004 & $\mathrm{Y}_{\mathrm{DI}}=12.4-1.5 \mathrm{X}_{1}-3.4 \mathrm{X}_{3}+92.7 \mathrm{X}_{4} \ldots \ldots \ldots$ (Eq.2) & 99 \\
October, 2004 & $\mathrm{Y}_{\mathrm{DI}}=12.78-2.9 \mathrm{X}_{1}+0.07 \mathrm{X}_{2} \ldots \ldots \ldots \ldots \ldots$. (Eq.3) & 72 \\
\hline
\end{tabular}

$\mathrm{X}_{1}=$ tree age, $\mathrm{X}_{2}=$ altitude, $\mathrm{X}_{3}=$ topography (slope), $\mathrm{X}_{4}=$ fog condition, $\mathrm{X}_{5}=$ forest opening

When $\mathrm{R}^{2}$ for individual site factors in each equation was $<30 \%$ and $<79 \%$, the factor was determined as minor and intermediate, respectively. When $\mathrm{R}^{2}$ was $>80 \%$, the factor was determined as major. Based on these criteria, degree of forest opening and fog condition were the major factors influencing gall rust disease incidence. Tree age, altitude and topography were minor factors.

\section{Meteorological factors influencing gall rust disease incidence in Brumas Estate}

Monthly data for sunshine hours, wind speed, humidity, rainfall, number of rain days, and temperature from January 1993 to January 2005 in Brumas Estate are 
presented in Figure 5. The wind direction was predominant from the northeast (not presented graphically). Rainfall amount, number of rainy days, sunshine hours and wind speed fluctuated more than mean temperature and relative humidity. However, stepwise multiple regression analysis showed that decreasing wind speed and increasing relative humidity were significant factors leading to increased gall rust disease incidence $(E q .4)$. Other factors were not significantly related to disease incidence and severity and were removed from the regression equation.

$$
\mathrm{Y}_{\mathrm{DI}}=-321-0.37 \mathrm{WS}+4.89 \mathrm{RH} \quad \mathrm{R}^{2}=100 \%
$$

where:

$\mathrm{Y}_{\mathrm{DI}}=$ estimated disease incidence, $\mathrm{Y}_{\mathrm{DS}}=$ estimated disease severity

$\mathrm{WS}=$ wind speed, $\mathrm{RH}=$ relative humidity
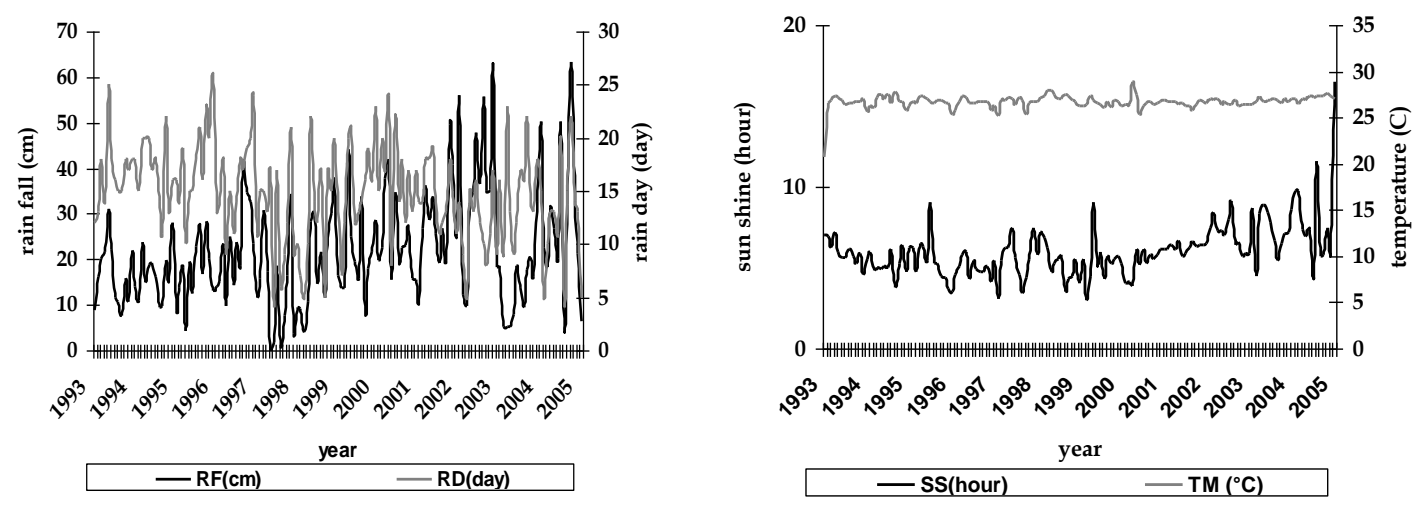

a

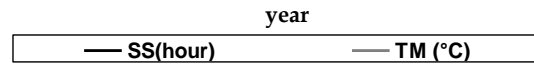

b

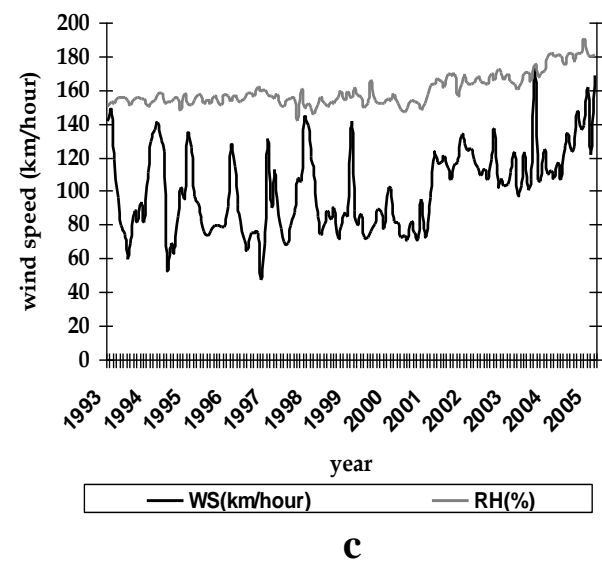

Figure 5. Data for number of sunshine hours, wind speed, humidity, rainfall, rainy days and temperature from 1993 to 2005 at Brumas Estate, Tawau, Sabah, Malaysia. $R F=$ rainfall $(\mathrm{cm})$, $R D=$ rain days (day), $T M=$ mean temperature $\left({ }^{\circ} \mathrm{C}\right), S S=$ duration of sunshine (hours), $W S=$ wind speed $(\mathrm{km} / \mathrm{h}), \mathrm{RH}=$ relative humidity $(\%)$.

\section{Actual and estimated gall rust disease incidence in Brumas Estate}

Based on the equations obtain from step-wise multiple regression, estimated gallrust disease incidence was calculated. When the estimated and actual values were not significantly different, local site and/or meteorological factors involved were accepted for that particular site and monitoring time. 
In October 2003, the site factors, topographical slope and forest opening determined disease incidence at all sites (Fig. $6 \mathrm{a}$ ); in addition, the meteorological factors, wind speed and relative humidity, determined disease incidence at all sites, except site $87 \mathrm{E}$ (Fig. 6b). Hence, in April 2004, the site factors tree age of trees, topographical slope and fog condition determined gall rust incidence at sites 109A, 94B and 1F (Fig. 7a); the meteorological factors including wind speed and relative humidity were determined gall rust disease incidence at all sites (Fig. $7 b$ ).

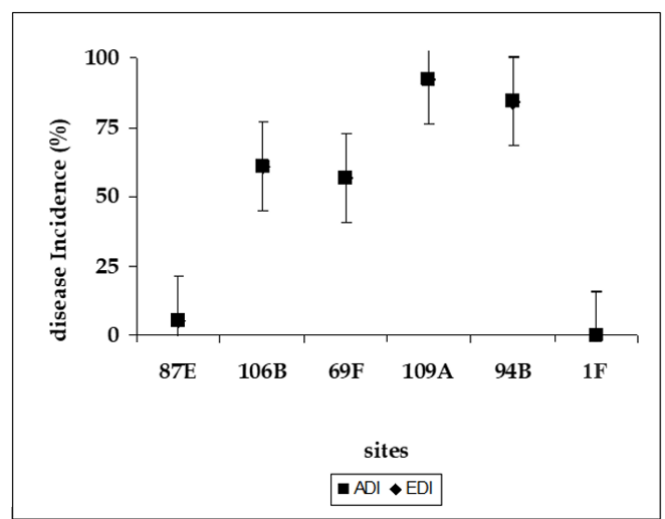

a

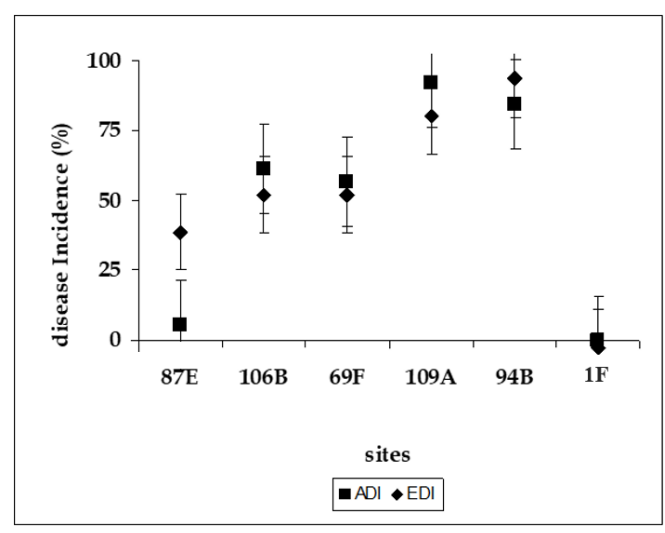

b

Figure 6. Actual disease incidence (ADI), estimated disease incidence (EDI) of gall-rust disease on $F$. moluccana, with estimated incidence based on linear regression of (a) local conditions, and (b) meteorological conditions in October 2003; vertical bars represent standard error

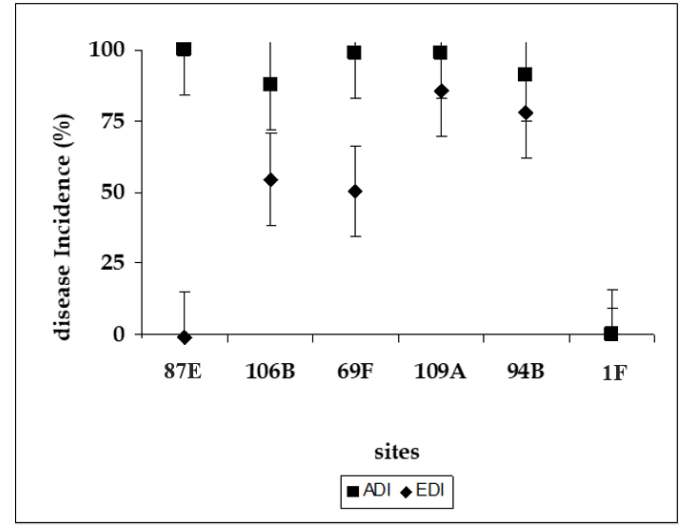

a

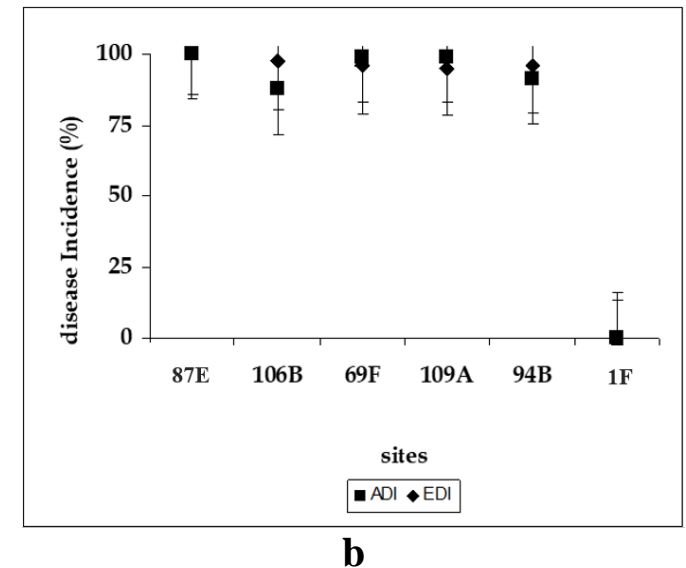

b

Figure 7. Actual disease incidence (ADI), estimated disease incidence (EDI) of gall-rust disease on F. moluccana, with estimated incidence based on linear regression of (a) local conditions, and (b) meteorological conditions in April, 2004; vertical bars represent standard error

In October 2004, local site and meteorological factors determined gall rust disease at sites 109A, 94B, and 1F. However, neither site nor meteorological factors appeared to influence gall rust disease incidence at site 106B. Only meteorological factors influenced disease incidence at site 87E, and at site 69F only local site factors (Fig. 8). 


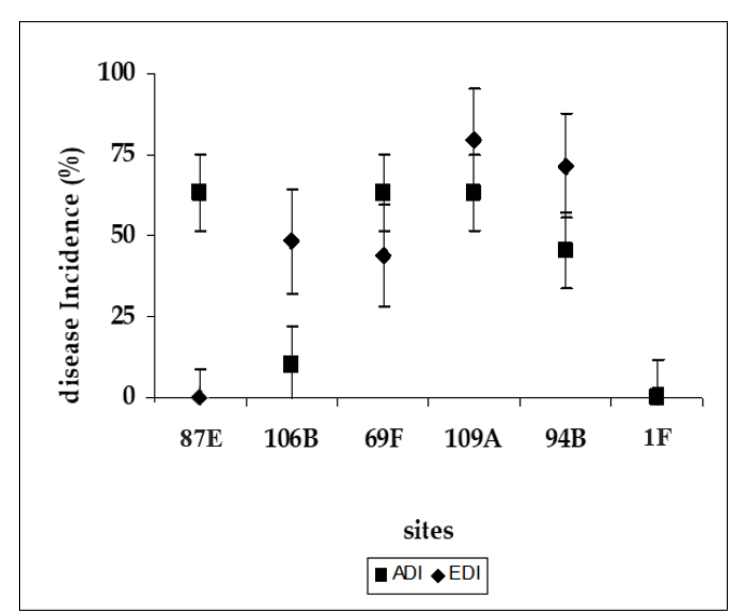

a

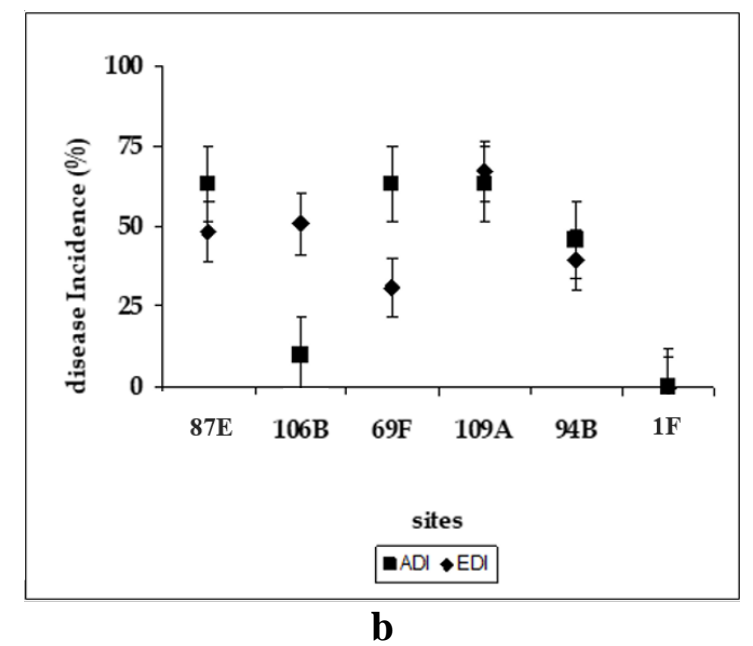

Figure 8. Actual disease incidence (ADI), estimated disease incidence (EDI) of gall-rust disease on F. moluccana, with estimated incidence based on linear regression of (a) local conditions, and (b) meteorological conditions in October, 2004; vertical bars represent standard error

\section{Discussion}

Climate change will alter the environmental conditions to which forest trees are adapted, and is likely to expose them to new pests and diseases (Koskela and Buck, 2006). In addition, location and prevailing climate can have an important impact on disease risk (Coakley, 1988). The occurrence of diseases like gall rust can differ from site to site or can be similar across vast regions, depending on complex interactions between the disease, the tree and the ecology of the site or region. In this study, gall rust disease incidence and severity at the sites investigated were dependent on monitoring time, and related to how the climate changed with time. In particular, relative humidity $\geq 90 \%$, low wind speed (about 30 to $50 \mathrm{~km} / \mathrm{h} / \mathrm{day}$ ), fog, steep slope, and being surrounded by high and dense vegetation were the dominant factors leading gall rust disease spread at Brumas Estate, Tawau, Sabah, Malaysia. However, in the absence of fog such as at site $1 \mathrm{~F}$, there was no disease development in spite of high relative humidity and low wind speed, conditions which are normally associated with fog development (Leipper, 1994). However, fog was not the only factor influencing the occurrence of gall rust disease at Brumas Estate. The absence of gall rust disease at site $1 \mathrm{~F}$ may be related to the long distance between site $1 \mathrm{~F}$ and other batai plantations. Secondly, this was the oldest site and the maturity of the trees may have provided resistance to infection or the trees by then have an ability to escape from the disease. Thirdly, the fogless and other meteorological conditions at this low altitude site were not suitable for disease development; thus the spores became dried or and eventually died, finally leading to disappearance of rust fungus.

Cooling, moistening and vertical mixing of air parcels of differing temperature and humidity influence fog formation (Leipper, 1994). When cool enough, the moisture in the air condenses out forming a radiation fog. Hence the formation of radiation fog on clear cool nights. Strong winds will mix the air and keep that shallow layer of cool air from forming near the ground. However upslope, fog can form in the presence of wind, even when the conditions at the surface are warm and humid. This fog will disappear when the wind dies out (Anonymous, 1991). The fog at Brumas Estate, Tawau, Sabah is 
likely to be radiation fog, and in general foggy conditions occurred at night or in the early morning, before sunrise.

Generally, fungi require wet periods to support their infection and development processes in the host. Under foggy or misty conditions, a "wetting period" occurs where the site is continuously wet with mist, fog, dew or rain. A preliminary study conducted before artificial inoculation of gall rust fungus on $F$. moluccana seedlings at Brumas Estate, showed that $U$. falcatarium requires fog as well as a wet period to ensure rust development. Teliospore germination and infection by basidiospores were not successful when seedlings were artificially inoculated at site $1 \mathrm{~F}$ which did not experience fog. However, artificial inoculation at the foggy sites (sites 109A and 94B) resulted in the teliospores germinating to form basidiospores, and early gall rust symptoms were observed three days after inoculation. A similar pattern was observed with teliospores of cedar-apple rust, Gymnosporangium juniperi-virginianae which only germinated to form basidiospores in wet periods at low temperature (Ellis et al., 1997). The maximum rate of spore discharge of apple scab fungus, Venturia inequalis was reached after two to three hours of wet conditions (Teviotdale and Gubler, 1997).

Large numbers of rusts require fog or mist as well as high relative humidity to ensure infection. White pine blister rust successfully infected Pinus strobus, P. monticola and $P$. lambertiana under cool, moist and foggy conditions (Maloy, 2001). Rust on rose leaves, including some species of Phragmidium spp. thrive in rainy, foggy or misty conditions (Anonymous, 2007). Uredinia of white pine blister rust fungus on Ribes were well-developed under foggy and wet conditions (Anonymous, 2001). Abundant pine blister rust caused by Cronartium ribicola and C. occidentale on Pinus monophylia and $P$. strobus mostly occurred under foggy and smoky conditions on the western slopes of the Pine Nut Range and the Wellington Hills, USA (Van Arsdel, 2001). The spores of Phragmidium rust species will only enter the rose tissue on the undersides of leaves, during rainy, dewy and foggy conditions (Anonymous, 2005). High-risk sites for white pine blister rust caused by Cronartium ribicola are frequently located on saddles, ridges, or mountain tops where summer fog is common, or in low-lying areas where cool, moist air flows or pools (Anonymous, 2007). A period that is foggy with intermittent showers during times of high levels of spore production is favourable for rust infection (Hoff, 1986).

A relative humidity of between 97 and 100 per cent for four or more hours can promote teliospore germination of Cronartium fusiformae on Pinus elliottii and Pinus taeda in Southern United States (Phelps and Czabator, 2001). In addition, (Chang et al., 1989) reported that relative humidity is one of the factors that affected gall rust spore germination of Endocronartium harknessii on Pinus contorta in North America. Abundant moisture and dew is required for basidiospore production of Cronartium ribicola and $C$. occidentale and for infection of Pinus monophylia and P. strobus. In addition, cool wet weather favours rust spread, while warmer drier air limits or prevents its spread (Van Ardsel and Krebill, 2001). The incidence of fusiform rust caused by the fungus Cronartium fusiforme also increased when relative humidity was $>98 \%$ (Kluepfel and Blake, 2006). In addition, cedar gall rust produced abundant spores during moist weather on rosaceous hosts in mid-spring at a time when new growth emerged (Chatfield et al., 2004).

Wind is probably the most important factor determining spore release of the Uredinales (Carter et al., 1970; Hirst, 1961; Smith, 1966; Sache, 2000). Uromycladium falcatarium with air-borne spores easily infects $F$. moluccana trees over a wide area and 
the spores can be introduced rapidly into new areas by wind (Sache, 2000). In this study, gall rust disease incidence and severity on $F$. moluccana were increased by slower wind speeds, i.e. between 30 to $53 \mathrm{~km} / \mathrm{h} /$ day. Uromycladium falcatarium teliospores need to germinate and produce basidiospores to directly infect host cells. If the wind speed is high, the basidiospores are more easily removed from the host surfaces and are thus unsuccessful in infecting host cells. Under almost similar conditions, teliospores of Phragmidium rust fungus on roses in temperate regions were removed from their host surface by strong winds, resulting in decreased disease incidence (Magyar and Manninger, 2004). In tropical regions of South-East Asia, which have high relative humidity as well as foggy conditions, gall rust disease is a potential threat. The Philippines, Indonesia and some parts of Malaysia where $F$. moluccana is planted are influenced by the global wind system under the equator line that could potentially dispersed $U$. falcatarium teliospores over a large geographical area. Since the wind blew predominantly from the north-east at Brumas Estate, there is a strong possibility that the spread of gall rust spores from the Philippines to Brumas Estate, Tawau, Sabah, Malaysia. Hence, establishing a collaborative network among SouthEast Asian countries for preventing and controlling gall rust disease is an important strategy to mitigate the disease.

Closed forests where the $F$. moluccana was surrounded by high and dense vegetation had a higher incidence of gall rust disease. These conditions promote low wind speeds, reduce air movement, and lead to shading and moisture retention. Studies in the Lakes State Forest showed that closed forest sites retain cool moist air and maintain conditions favourable for basidiospore deposition and infection of white pine blister rust (Van Arsdel and Krebill, 2001). Consequently, blister rust disease incidence was higher than in intermediate or open forest sites. Topography was also an important determinant of gall rust disease incidence at Brumas Estate. While not a direct effect, topography influences relative humidity, fog formation and wind speed. In hilly or undulating areas associated with steep slopes such as occur at the Brumas Estate, cool air settles into the valleys and fog forms while the hilltops remain clear. In other areas of the estate, light winds may have prevented fog formation, particularly in flatter areas; however valleys in the hilly or undulating areas are sheltered from the wind (Anonymous, 2006). Thus, in undulating areas such as sites $106 \mathrm{~B}$ and 94B at Brumas Estate, the F. moluccana trees were more affected by gall rust those in the flatter areas.

\section{Conclusion}

The occurrence of gall rust disease can differ from site to site or can be similar across vast regions, depending on the complex interaction between the disease, the tree, the environment and the human management practices at the site or in the region. The interactions between local site condition and meteorological factors at the time of monitoring were determined by the level of gall rust disease incidence and severity. More open sites, flat topography, absence of fog, greater age and lower altitude were significant local site conditions that reduced gall rust disease incidence and severity. High relative humidity and low wind speed promoted gall rust disease development. Based on Brumas meteorological data from 1993 to March 2005, it was noted that the wind blew predominantly from the north-east at Brumas Estate, possibly leading to the spread of gall rust spores from the Philippines to Brumas Estate, Tawau, Sabah, Malaysia. 
Acknowledgements. This work was supported by Malaysian Tecnical Cooperation Programme (MTCP) year 2003 to 2007, Sabah Softwood Berhad (SSB), Tawau Malaysia and Higher Education Indonesia.

\section{REFERENCES}

[1] Anggraeni, I. (2006): Penyakit karat puru pada sengon (Paraserianthes falcataria) (Gall Rust Disease on Paraserianthes falcataria). - Paper on Scientific Discussion. Pusat Penelitian Hutan Tanaman. Probolinggo, Indonesia.

[2] Anonymous (1991): Fog formation, where and why? - http://www.newton. dep.anl.gov/askasci/gen99/gen9(9301):htm. Accessed on 03 February, 2007.

[3] Anonymous (1993): Gall Rust Disease on F. moluccana Plantation in Sabah, Malaysia. Annual Report of SSB Company, Sabah. Malaysia (unpublished).

[4] Anonymous (2001): Forest Pathology-Rusts. - http://www.forestpathology.org/rust.html. Accessed on 28 January 2007.

[5] Anonymous (2005): Rust on Roses. - The Scotts Company LLC, Marysville, Ohio.

[6] Anonymous (2007): Rust on Rose Leaves. - http://www.rosemagazine.com /articles02/pages/rust.asp. Accessed on 28 January 2007.

[7] Bowen, K. L. (2003): Plant Disease Epidemiology. - CRC Press, London.

[8] Braza, R. D. (1997): Gall rust disease of Paraserianthes falcataria in the Philippines. Forest, Farm, \& Community Tree Research Reports 2: 61-62.

[9] Carter, M. V., Moller, W. J., Pady, S. M. (1970): Factors affecting uredospore production and dispersal in Tranzschelielia discolor. - Australian Journal of Agricultural Research 21: 905-914.

[10] Chang, K. F., Blenis, P. V., Hiratsuka, Y. (1989): Survival of Endocronartium harknesii teliospore in a simulated airborne state. - Canadian. J. Botanical 67: 928-932.

[11] Chatfield, J., Nameth, S., Ellet, C. W. (2004): Cedar Rust Diseases of Ornamental Plants. - Extension Fact Sheet, HYG-3055-96. The Ohio State University, Columbus, USA.

[12] Chester, K. S. (1959): How Sick is the Plant. - In: Horsfall, J. G. H., Diamond, A. (eds.) Plant Pathology Vol. 1., Academic Press, Inc, New York.

[13] Coakley, S. M. (1988): Variation in climate and prediction of risk in plants. - Annual Review Phytopathology 26: 163-181.

[14] Doungsaard, C, McTaggart, A. R., Geering, A. D. W., Dalisay, T. U., Ray, J, Shivas, R. G. (2015): Uromycladium falcatarium sp. nov., the cause of gall rust on Paraserianthes falcataria in south-east Asia. - Australasian Plant Pathol. 44: 25-30.

[15] Ellis, M. A., Chatfield, J., Drapper, E. (1997): Scab of Apple and Crab Apple. - The Ohio State University Extension Factsheet HYG-3003-94.

[16] Eusobio, M. A., Sinohin, V. O., Dayan, M. P. (1990): Gall rust disease of Albizia falcataria (L.) Beck. - Research Information Series on Ecosystems 1990: special issue.

[17] Franje, N. S., Alovera, H. C., Isidora, M. O., Expedito, E. D. C., Revelieta, B. A. (1993): Gall Rust of Falcata (Albizzia falcataria (L.)) Beck: Its Biology and Identification. Northern Mindanau Consortium for Agriculture Resources Research and Development (NOMCARRD), Mindanao, The Philippines.

[18] Gultepe, I. (2007): Fog and Boundary Layer Clouds: Fog Visibility and Forecasting. Birkhauser Verlag, Basel, Switzerland.

[19] Hamilton, E. D. (1959): Studies on the air spora. - Acta Allergologica 13: 143-175.

[20] Hansen, E. M., Stone, J. K., Capitano, B. R., Rosso., P., Sutton., W. Winton., L., Kanaskie, A., Mc Williams, M. G.(2000): Incidence and impact of Swiss needle cast in forest plantation of Douglas-fir in Coastal Oregon. - Plant Disease 84: 773-778.

[21] Hirst, J. M. (1961): The aerobiology of Puccinia graminis uredospores. - Transactions of the British Mycological Society 44: 138-139.

[22] Hoff, R. J.(1986): Susceptibility of Pine Populations to Western Gall Rust-Central Idaho. - Research Note INT-354. Intermountain Research Station, Ogden, Utah, USA. 
[23] Kasno, A., Hadi, S. (2005): Pest and Diseases of Forest Trees and General Impression on the Implementation of Reforestation in the Post Mined Area of PT. INCO, Sorowako, South Sulawesi. - Visit Report Department of Silviculture Faculty of Forestry, Bogor Agricultural University. Bogor, Indonesia.

[24] Kluepfel, M., Blake, J. H. (2006): Pine Diseases. - Home and Garden Information Center. CLEMSON Extension. Clemson University, South Carolina.

[25] Koskela, J., Buck. A. (2006): Genetic diversity helps to mitigate the impacts of climate change. - Scientific Summary Published in IUFRO News 4.

[26] Lee, S. S. (2004): Diseases and potential threats to Acacia mangium plantation in Malaysia. - Unasylva 217(55): 31-35.

[27] Leipper, D. F. (1994): Fog on the United States West Coast: a review. - Bulletin of American Meteorology Society 75: 229-240.

[28] Magyar, D., Manninger, K. (2004): Effects of metrological condition on uredo-and teliospore of rust. Cereal rusts and powdery mildews Bulletin. http://www.Crpmb.org/2004/1029magyar. Accessed on 7 March 2005.

[29] Maloy, O. C. (2001): White pine blister rust. - Online Plant Health Progress. DOI: 10.1094/PHP-2001-0924-01-HM.

[30] Moore, W. F.(1970): Origin and spread of Southern corn leaf blight in 1970. - Plant Disease Reproductive 54: 1104-1108.

[31] Morris, M. J. (1987): Biology of the Acacia gall rust, Uromycladium falcatarium. - Plant Pathology 36: 100-106.

[32] Old, K. M., Cristovao, C. S. (2003): A rust epidemic of the coffee shade tree (Paraserianthes falcataria) in East Timor. - ACIAR Proceedings No. 13: 139-145.

[33] Phelps, W. R., Czabator, F. L. (2001): Fusiform Rust of Southern Pines. - Forest Insect and Disease Leaflet 26. USDA, Washington, DC.

[34] Rahayu, S., Lee, S. S., Noraini, A. S. (2010): Uromycladium falcatarium, the gall rust fungus from Falcataria moluccana (Miq.) Barneby and J. W. Grimes in Malaysia and Indonesia. - Journal of Mycoscience 51: 149-153.

[35] Rosso, P. H., Hansen, E. M. (2003): Predicting Swiss Needle Cast Disease Distribution and Severity in Young Douglas-Fir Plantation in Coastal Oregon. - The American Phytopathological Society, Saint Paul, MN. No. P-2003-0513-01R.

[36] Sache I. (2000): Short distance dispersal of wheat rust spores by wind and rain. Agronomie 20: 757-767.

[37] Serdani, M. (2001): The Acacia Gall Rust. - http://www.arc.agric.za. Accessed on 1 November 2003.

[38] Smith, R. S. (1966): The liberation of cereal stem rust uredospores under various environmental conditions in wind tunnel. - Transactions of the British Mycological Society 49: 33-41.

[39] Teviotdale, B. L., Gubler, W. D. (1997): Apple Scab. UC Pest Management Guidelines. University of California Statewide Integrated Pest Management Project.

[40] Van Arsdel, E. P., Krebill, R. G. (2001): Climatic Distribution of Blister Rusts on Pinyon and White Pines in the USA. - In: Geils, B. (ed.) Proceedings 4th IUFRO Rusts of Pines, 1995. Working Party Conference, Tsukuba, pp. 127-133..

[41] Vourinen, P., Helander, M. L. (1995): Variation in airborne urediniospore concentration of Melampsoridium betulinum. - Aerobiologia 11: 259-264. 